NASA/TM-2005-213888

\title{
Overview of Advanced Electromagnetic Propulsion Development at NASA Glenn Research Center
}

Eric J. Pencil and Hani Kamhawi

Glenn Research Center, Cleveland, Ohio

James H. Gilland

Ohio Aerospace Institute, Brook Park, Ohio

Lynn A. Arrington

QSS Group, Inc., Cleveland, Ohio 
Since its founding, NASA has been dedicated to the advancement of aeronautics and space science. The NASA Scientific and Technical Information (STI) Program Office plays a key part in helping NASA maintain this important role.

The NASA STI Program Office is operated by Langley Research Center, the Lead Center for NASA's scientific and technical information. The NASA STI Program Office provides access to the NASA STI Database, the largest collection of aeronautical and space science STI in the world. The Program Office is also NASA's institutional mechanism for disseminating the results of its research and development activities. These results are published by NASA in the NASA STI Report Series, which includes the following report types:

- $\quad$ TECHNICAL PUBLICATION. Reports of completed research or a major significant phase of research that present the results of NASA programs and include extensive data or theoretical analysis. Includes compilations of significant scientific and technical data and information deemed to be of continuing reference value. NASA's counterpart of peerreviewed formal professional papers but has less stringent limitations on manuscript length and extent of graphic presentations.

- TECHNICAL MEMORANDUM. Scientific and technical findings that are preliminary or of specialized interest, e.g., quick release reports, working papers, and bibliographies that contain minimal annotation. Does not contain extensive analysis.

- CONTRACTOR REPORT. Scientific and technical findings by NASA-sponsored contractors and grantees.
- CONFERENCE PUBLICATION. Collected papers from scientific and technical conferences, symposia, seminars, or other meetings sponsored or cosponsored by NASA.

- SPECIAL PUBLICATION. Scientific, technical, or historical information from NASA programs, projects, and missions, often concerned with subjects having substantial public interest.

- TECHNICAL TRANSLATION. Englishlanguage translations of foreign scientific and technical material pertinent to NASA's mission.

Specialized services that complement the STI Program Office's diverse offerings include creating custom thesauri, building customized databases, organizing and publishing research results ... even providing videos.

For more information about the NASA STI Program Office, see the following:

- Access the NASA STI Program Home Page at http://www.sti.nasa.gov

- E-mail your question via the Internet to help@sti.nasa.gov

- Fax your question to the NASA Access Help Desk at 301-621-0134

- Telephone the NASA Access Help Desk at 301-621-0390

- Write to:

NASA Access Help Desk

NASA Center for AeroSpace Information 7121 Standard Drive

Hanover, MD 21076 
NASA/TM-2005-213888

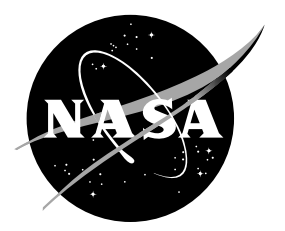

\section{Overview of Advanced Electromagnetic Propulsion Development at NASA Glenn Research Center}

Eric J. Pencil and Hani Kamhawi

Glenn Research Center, Cleveland, Ohio

James H. Gilland

Ohio Aerospace Institute, Brook Park, Ohio

Lynn A. Arrington

QSS Group, Inc., Cleveland, Ohio

Prepared for the

41st Joint Propulsion Conference and Exhibit cosponsored by the AIAA, ASME, SAE, and ASEE

Tucson, Arizona, July 10-13, 2005

National Aeronautics and

Space Administration

Glenn Research Center 


\section{Acknowledgments}

The authors would like to express their gratitude for the support of the Energetics Heritage project managed by Randall Speth and David Hoffman. The authors would like to express their gratitude for the high dedication and workmanship of Glenn technicians in supporting this work, especially Dennis Rogers, James Coy, Donna Neville, and Valarie Roundtree.

Available from

NASA Center for Aerospace Information 7121 Standard Drive

Hanover, MD 21076
National Technical Information Service 5285 Port Royal Road Springfield, VA 22100 


\title{
Overview of Advanced Electromagnetic Propulsion Development at NASA Glenn Research Center
}

\author{
Eric J. Pencil and Hani Kamhawi \\ National Aeronautics and Space Administration \\ Glenn Research Center \\ Cleveland, Ohio 44135 \\ James H. Gilland \\ Ohio Aerospace Institute \\ Brook Park, Ohio 44142 \\ Lynn A. Arrington \\ QSS Group, Inc. \\ Cleveland, Ohio 44135
}

\begin{abstract}
NASA Glenn Research Center's Very High Power Electric Propulsion task is sponsored by the Energetics Heritage Project. Electric propulsion technologies currently being investigated under this program include pulsed electromagnetic plasma thrusters, magnetoplasmadynamic thrusters, helicon plasma sources as well as the systems models for high power electromagnetic propulsion devices. An investigation and evaluation of pulsed electromagnetic plasma thruster performance at energy levels up to 700 Joules is underway. On-going magnetoplasmadynamic thruster experiments will investigate applied-field performance characteristics of gas-fed MPDs. Plasma characterization of helicon plasma sources will provide additional insights into the operation of this novel propulsion concept. Systems models have been developed for high power electromagnetic propulsion concepts, such as pulsed inductive thrusters and magnetoplasmadynamic thrusters to enable an evaluation of mission-optimized designs.
\end{abstract}

\section{Introduction}

The National Aeronautics and Space Administration (NASA) Glenn Research Center's Very High Power Electric Propulsion task is currently supported by the Energetics Heritage Project. The Energetics Heritage Project is formerly an element of the Aerospace Technology Enterprise's (Code R) Mission and Science Measurement Technology theme, which was transitioned to the Human \& Robotics Technology theme in the Office of Exploration prior to being transferred to the Exploration Systems Research \& Technology theme in the newly formed Exploration Systems Mission Directorate. The Energetics Heritage Project addresses technology development through an improved understanding of the fundamental physics and the identification and resolution of design challenges to advance the technology. Current activities under this task include the development of high performance pulsed electromagnetic plasma thrusters, gas-fed magnetoplasmadynamic (MPD) thrusters, helicon plasma sources, and systems models for advanced electromagnetic propulsion thrusters. Given that funding for the Energetics Heritage Project ends after Fiscal Year 2005, this paper will provide the status of the activities remaining in that effort.

\section{Pulsed Electromagnetic Plasma Thruster Development}

Two longstanding goals in electric propulsion are to reduce total system mass and to increase performance capabilities of the system. One approach for achieving either goal is to investigate performance improvements to thruster efficiency. Improvements to thrust efficiency can be utilized to reduce total system mass through the reduction in propellant mass, assuming the reductions in propellant savings are greater than the system dry mass penalties. In power-limited satellites, improvements in thruster efficiency can enhance propulsion capabilities by increasing available thrust to either decrease orbit transfer trip times or to improve drag make-up capabilities of a satellite (Ref. 1). 


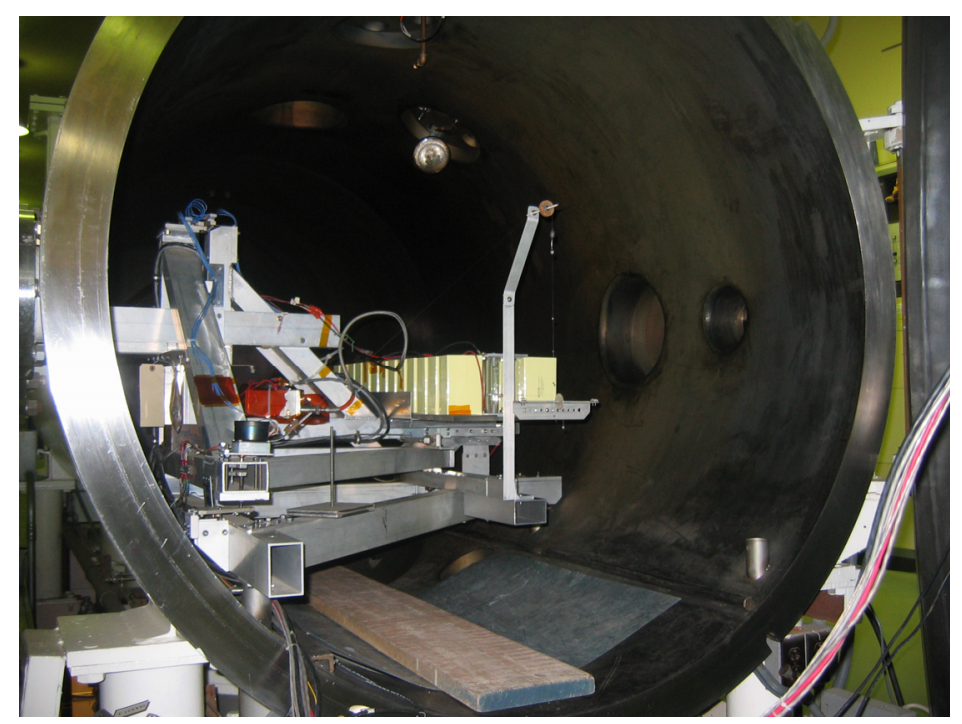

Figure 1.- - Laboratory thruster mounted on PPT thrust stand in VF3 at NASA GRC.

Improvements to the operational boundaries of the pulsed electromagnetic plasma thruster performance map have been investigated through a number of approaches under the Energetics program. Performance evaluation of additives to polytetrafluoroethylene (PTFE) has shown that small amounts of carbon added to PTFE significantly reduced propellant ablation rates, while marginally changing thrust. The improvements over nominal PTFE depended on several factors including discharge energy (Ref. 2), electrode geometry (Ref. 3), and propellant composition (Ref. 4). In addition increasing discharge energy with any propellant has been shown to improve thrust efficiency (Refs. 5 to 8). Recently Kamhawi, et al. (Ref. 9) have investigated thruster operation at higher discharge energies with two thruster configurations. The first thruster configuration (Fig. 1) was operated with three capacitor arrangements to provide a total discharge capacitance of $100 \mu \mathrm{F}, 180 \mu \mathrm{F}$, and $260 \mu \mathrm{F}$. This thruster configuration was operated over a range of discharge energies from 50 to $700 \mathrm{~J}$ with thrust efficiencies ranging from 4 to 35 percent as shown in Figure 2. The second thruster configuration was operated with a total discharge capacitance of $260 \mu \mathrm{F}$. This thruster configuration was operated over a range of discharge energies from 300 to $700 \mathrm{~J}$ with thrust efficiencies ranging from 23 to 37 percent. Discharge current waveforms were collected and compared to predictions from a pulse forming network circuit model. Future work will evaluate various electrode and propellant configurations (Ref. 10).

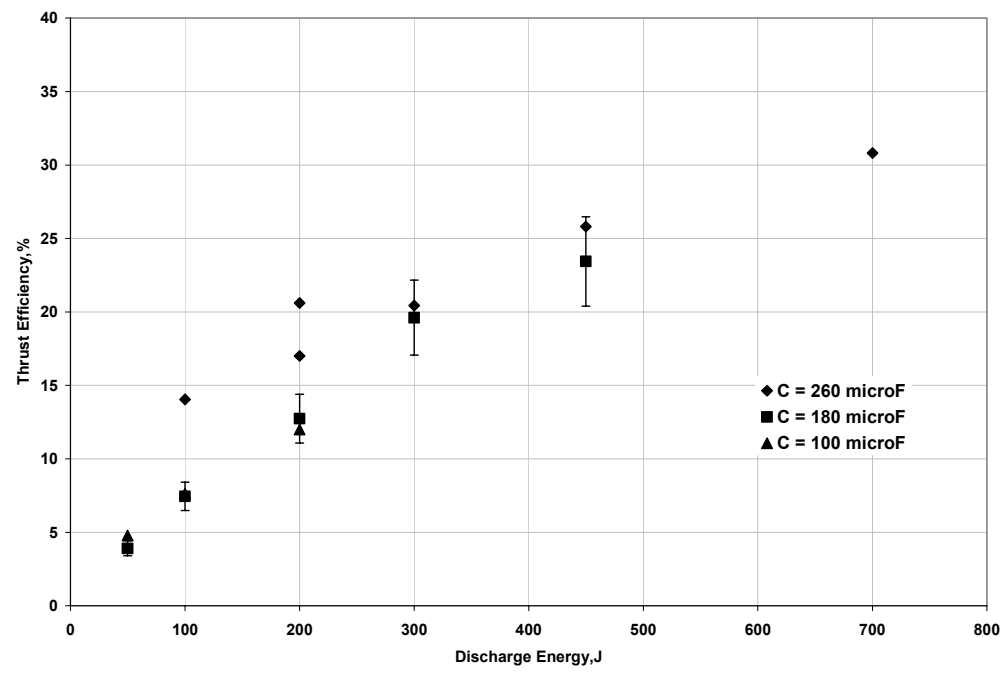

Figure 2.-Configuration thrust efficiency magnitudes for discharge energy levels between 50 and $700 \mathrm{~J}$. 


\section{High Power Magnetoplasmadynamic Thruster Development}

High power magnetoplasmadynamic thrusters are being developed as a propulsion system for cargo transport and possibly piloted human to Mars bases and the outer planets and robotic deep space exploration missions. Electromagnetic thrusters in the laboratory have demonstrated the ability to produce significantly higher thrust densities than electrostatic electric propulsion systems. The ability to generate high thrust densities results in decreased system complexity through reductions in the number of thrusters required to perform a given mission. NASA GRC is developing and testing quasi-steady MW-class thrusters as a prelude to steady-state high power thruster tests. Quasi-steady testing will focus on improving performance, specifically thrust efficiency. Previous work on the high power pulsed thruster test facility and preliminary performance data for a quasi-steady baseline MPD thruster geometry were presented (Ref. 11) and are shown in Figure 3.

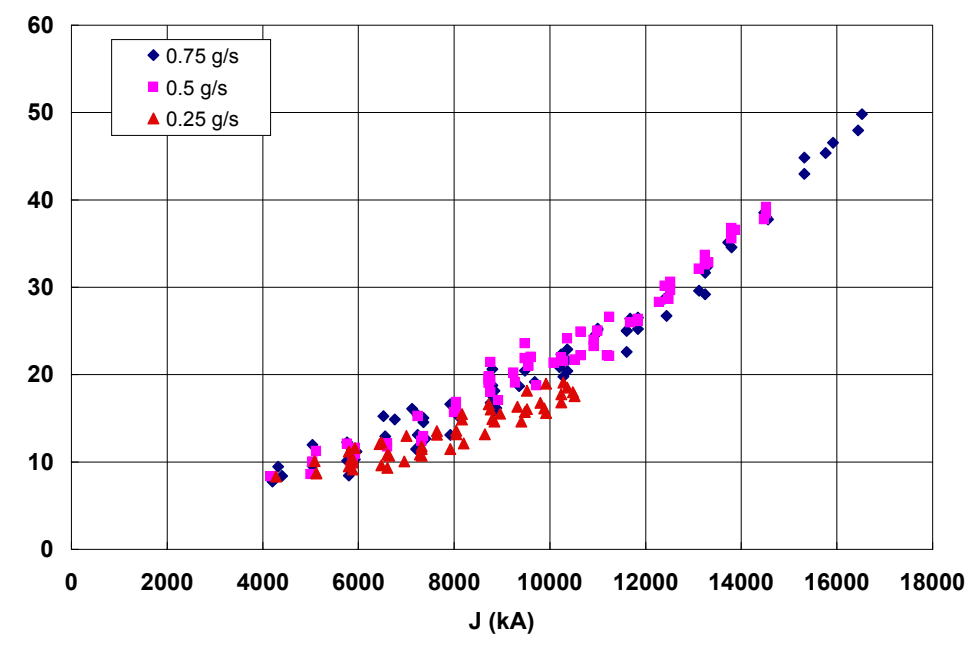

Figure 3.- Self-field MPD thruster quasi-steady performance data with argon.

Future work will focus on applied-field performance characterization of the baseline thruster geometry (Ref. 12) as shown in Figure 4 as well as an interrogation of the thruster plasma flowfield with an array of intrusive and nonintrusive diagnostics. The extension of the work to applied-field thrusters requires only minor modifications to the thrust stand to eliminate applied-field tare effects. Modifications underway include incorporating features found on the NASA GRC pulsed plasma thruster thrust stand such as a magnetic damper and linear variable displacement transducer system. The damping system is required to cancel magnet-induced oscillations prior to the discharge. The intent of the quasi-steady tests is to improve the understanding of MPD behavior. Insights gained from this work are anticipated to be applicable to the MPD thruster field in general, independent of propellant.

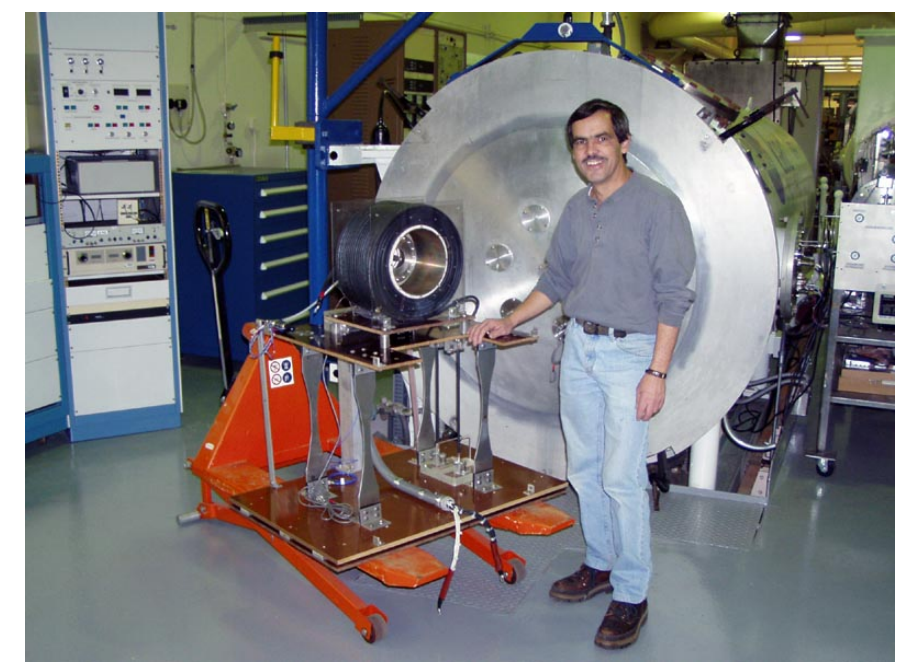

Figure 4.-Baseline applied-field MPD thruster installed on pulsed thrust stand. 


\section{Helicon Plasma Source Development}

Helicon plasma sources offer several unique features such as high-density plasmas $\left(10^{19} \mathrm{~m}^{-3}\right)$ at relatively low powers (100's of watts) as compared to other electric propulsion thrusters as well as the promise of electrode-less electric propulsion. The main benefit of electrode-less electric propulsion is the potential mitigation of electrode erosion through the elimination of thruster electrodes from high-energy plasma environment in electric propulsion thruster discharge chambers. Low-power, high-density plasma sources offer the potential to decrease thruster size at a given power level. However, thruster scale helicon sources represent a departure from the larger laboratory devices currently under investigation.

Potential applications include incorporating helicon plasma sources into the discharge chamber of traditional devices such as hall or ion thrusters (Ref. 13), using the helicon waves to heat and accelerate plasmas through a proposed double layer effect (Ref. 14), or operating with propellants derived from extraterrestrial resources (Refs. 15 and 16). Initial focus was on the investigation of a $13.56 \mathrm{MHz}, 300 \mathrm{~W}$ helicon plasma source, which has demonstrated plasma generation (Fig. 5) but poor coupling. However, related dispersion calculations indicated that higher frequencies might allow better coupling (Ref. 17). As a result the experiment has been upgraded to include a tunable 10-100 MHz, $300 \mathrm{~W}$ microwave power supply and an extended magnetic coil.

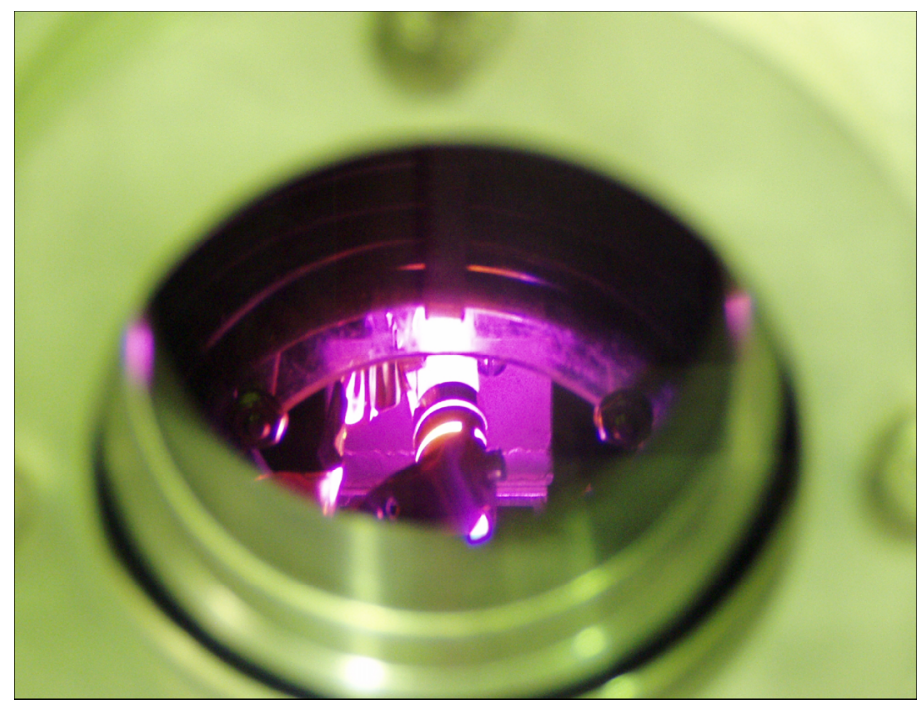

Figure 5.-300 W helicon plasma source operating at $13.5 \mathrm{MHz}$ in vacuum.

\section{Mission and Systems Models for Advanced Electromagnetic Thrusters}

An on-going activity at NASA GRC is the development of thruster models, which can be used to optimize thruster designs based on specific exploration mission objectives. These models are designed to be incorporated in mission trajectory optimization codes as needed in application to Exploration and Science mission analysis (Ref. 18). The performance models are based on input of specific impulse and power, and yield efficiency and thruster operating parameters. The concepts of interest include self-field and applied-field magnetoplasmadynamic thrusters, pulsed inductive thrusters, and helicon/electron cyclotron resonance thrusters. Self-field and applied-field MPD thruster models have been developed for use in mission studies and provide estimates for performance and mass (Refs. 18 and 19). An initial physics-based performance model has also been derived for the pulsed inductive thruster (Ref. 20) and has been incorporated into a preliminary set of scaling relations (Ref. 21) as shown in Figure 6. Similarly, a preliminary zeroth order model for helicon/electron cyclotron resonance thruster concepts has been developed (Ref. 15). While the ideal propulsion performance of radiofrequency (rf) concepts has been modeled in terms of fundamentals, several unknowns at both the physics and engineering levels remain. For example, the physics of plasma expansion and detachment in a magnetic field remain as outstanding questions in terms of feasibility and efficiency, which will strongly affect performance. The design, power efficiency, lifetime, and mass of 10 to $1000 \mathrm{~kW}$, space rated rf power systems is an engineering unknown with little specific design work to date. These fundamental and systems-level issues are still being investigated experimentally and analytically. 


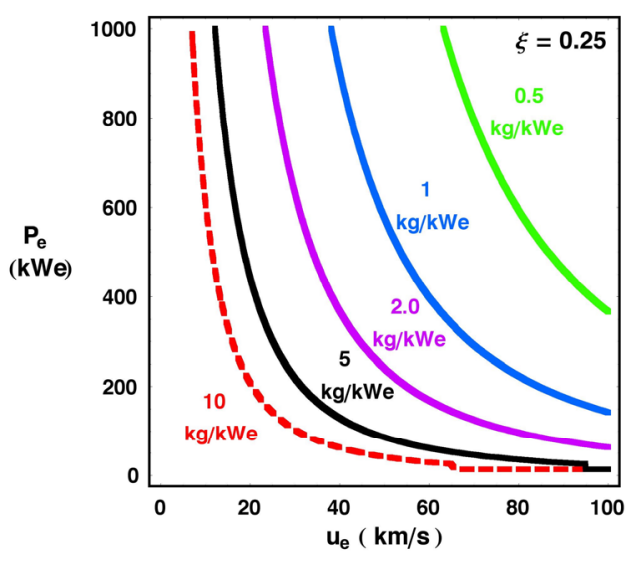

Figure 6.-PIT scaling relationships for high power applications.

\section{Conclusion}

Electric propulsion technologies currently being investigated under the Energetics project include pulsed electromagnetic plasma thrusters, magnetoplasmadynamic thrusters, helicon plasma sources as well as the systems models for high power electromagnetic propulsion devices. An investigation and evaluation of pulsed electromagnetic plasma thruster performance at energy levels up to 700 Joules is underway and has demonstrated efficiencies up to 37 percent. On-going magnetoplasmadynamic thruster experiments will investigate applied-field performance characteristics of gas-fed MPDs for comparison to self-field performance data. Plasma characterization of helicon plasma sources will provide additional insights into the operation of this novel propulsion concept and its effective application in electric propulsion systems. Systems models have been developed for high power electromagnetic propulsion concepts, such as pulsed inductive thrusters and magnetoplasmadynamic thrusters to enable an evaluation of optimized designs for exploration and science mission objectives.

\section{References}

1. Pencil, E.J., Kamhawi, H., and Arrington, L.A., "Overview of NASA's Pulsed Plasma Thruster Development Program," AIAA-2004-3455, 40th Joint Propulsion Conference, Fort Lauderdale, FL, July 2004.

2. Pencil, E.J., and Kamhawi, H., "Alternate Fuel Evaluation in a 100 Joule Class Pulsed Plasma Thruster," AIAA-2003-5171, 39th Joint Propulsion Conference, Huntsville, AL, July 2003.

3. Kamhawi, H., Pencil, E.J., and Haag, T.W., "High Thrust-to-Power Parallel-Rail Pulsed Plasma Thruster Design," AIAA-2002-3975, 38th Joint Propulsion Conference, Indianapolis, IN, July 2002.

4. Pencil, E.J., Kamhawi, H., Arrington, L.A., and Warren, W.B., "Evaluation of Alternate Propellants for Pulsed Plasma Thrusters," IEPC-01-047, Proceedings of the 27th International Electric Propulsion Conference, Pasadena, CA, October 2001.

5. Palumbo, D.J., and Guman, W.J., "Effects of Propellant and Electrode Geometry on Pulsed ablative Plasma Thruster Performance," J. Spacecraft, Vol. 13, No. 3, March 1976, pp. 163-167.

6. Popov, G., et al., "Experimental Study of Plasma Parameters in High Efficiency Pulsed Plasma Thrusters," IEPC-01-163, Proceedings of the 27th International Electric Propulsion Conference, Pasadena, CA, October 2001.

7. Kazeev, M.N., et al., "Dynamics and Distribution of Electron Density in the Channel of Pulsed Plasma Thruster," AIAA-2002-4119, July 2002.

8. Antropov, N., et al., "Development and Refinement of Highly Efficient 150 J APPT," IEPC 03-061, Proceedings of the 28th International Electric Propulsion Conference, Toulouse, France, March 2003.

9. Kamhawi, H., Arrington, L.A., Pencil, E.J., and Haag, T.W.," Performance Evaluation of a High Energy Pulsed Plasma Thruster," AIAA-2005-3695, 41st Joint Propulsion Conference, Tucson, AZ, July 2005.

10. Kamhawi, H., Arrington, L.A., Pencil, E.J., and Haag, T.W., "Extended Performance Evaluations of a High Energy Pulsed Plasma Thruster," to be published at the 29th International Electric Propulsion Conference, Princeton, NJ, October 2005.

11. LaPointe, M.R., Strzempkowski, E., Pencil, E.J., "High Power MPD Thruster Performance Measurements," AIAA-20043467, 40th Joint Propulsion Conference, Fort Lauderdale, FL, July 2004.

12. Pencil, E.J., Gilland, J.H., Foster, J.E., "Inert Propellant MPD Thruster Performance Measurements," to be presented at the 29th International Electric Propulsion Conference, Princeton, NJ, October 2005.

13. Gilland, J.H. and Hershkowitz, N., "Application of a Helicon Discharge to Electric Propulsion,” AIAA Paper No. 98-3934, 1998. 
14. Charles, C., and Boswell, R., "Current-free double-layer formation in a high-density helicon discharge," Appl. Phys. Lett. 82 (9) 2003.

15. Gilland, J. "Helicon Wave Physics Impacts on Electrodeless Thruster Design," IEPC Paper No. 150, Proceedings of the 28th International Electric Propulsion Conference, Toulouse, France, March 2003.

16. Gilland, J. "Mission Impacts of In-Situ Propellant Usage for Electric Propulsion Vehicles," AIAA-2005-4267, 41st Joint Propulsion Conference, Tucson, AZ, July 2005.

17. Gilland, J. and Piefer, G., "Small Helicon Plasma Source Experiments," AIAA-2004-3939, Fort Lauderdale, FL, July 2004.

18. McGuire, M.L.; Borowski, S.K.; Mason, L.M.; and Gilland, J.G., "High Power MPD Nuclear Electric Propulsion (NEP) for Artificial Gravity HOPE Missions to Callisto,"NASA/TM-2003-212349; E-13937, December 2003.

19. Gilland, J. and Johnston, G., "MPD Thruster Performance Analytic Models," presented at 2003 STAIF Conferences, Albuquerque, NM, Feb. 2003.

20. Mikellides, P., "Pulsed Inductive Thruster (PIT): Modeling and Validation Using the MACH2 Code," NASA/CR—2003212714, December 2003.

21. Gilland, J.E., "Systems Modeling of Electromagnetic Thruster Options," AIAA-2005-4269, 41st Joint Propulsion Conference, Tucson, AZ, July 2005. 
Public reporting burden for this collection of information is estimated to average 1 hour per response, including the time for reviewing instructions, searching existing data sources, gathering and maintaining the data needed, and completing and reviewing the collection of information. Send comments regarding this burden estimate or any other aspect of this collection of information, including suggestions for reducing this burden, to Washington Headquarters Services, Directorate for Information Operations and Reports, 1215 Jefferson Davis Highway, Suite 1204, Arlington, VA 22202-4302, and to the Office of Management and Budget, Paperwork Reduction Project (0704-0188), Washington, DC 20503.

\begin{tabular}{|l|l|l}
\hline 1. AGENCY USE ONLY (Leave blank) & $\begin{array}{c}\text { 2. REPORT DATE } \\
\text { September } 2005\end{array}$ & $\begin{array}{r}\text { 3. REPORT TYPE AND DATES COVERED } \\
\text { Technical Memorandum }\end{array}$ \\
\hline
\end{tabular}

\section{TITLE AND SUBTITLE} 5. FUNDING NUMBERS

Overview of Advanced Electromagnetic Propulsion Development at NASA Glenn Research Center

\section{AUTHOR(S)}

WBS-22-612-50-81-14

Eric J. Pencil, Hani Kamhawi, James H. Gilland, and Lynn A. Arrington

7. PERFORMING ORGANIZATION NAME(S) AND ADDRESS(ES)

National Aeronautics and Space Administration

John H. Glenn Research Center at Lewis Field

Cleveland, Ohio 44135-3191

8. PERFORMING ORGANIZATION REPORT NUMBER

E-15259

\section{SPONSORING/MONITORING AGENCY NAME(S) AND ADDRESS(ES)}

National Aeronautics and Space Administration

Washington, DC 20546-0001

10. SPONSORING/MONITORING AGENCY REPORT NUMBER

NASA TM-2005-213888

AIAA-2005-4227

\section{SUPPLEMENTARY NOTES}

Prepared for the 41st Joint Propulsion Conference and Exhibit cosponsored by the AIAA, ASME, SAE, and ASEE, Tucson, Arizona, July 10-13, 2005. Eric J. Pencil and Hani Kamhawi, NASA Glenn Research Center; James H. Gilland, Ohio Aerospace Institute, 22800 Cedar Point Road, Brook Park, Ohio 44142; and Lynn A. Arrington, QSS Group, Inc., 21000 Brookpark Road, Cleveland, Ohio 44135. Responsible person, Eric J. Pencil, organization code RPP, 216-977-7463.

12a. DISTRIBUTION/AVAILABILITY STATEMENT

12b. DISTRIBUTION CODE

Unclassified - Unlimited

Subject Category: 20

Available electronically at http://gltrs.grc.nasa.gov

This publication is available from the NASA Center for AeroSpace Information, 301-621-0390.

13. ABSTRACT (Maximum 200 words)

NASA Glenn Research Center's Very High Power Electric Propulsion task is sponsored by the Energetics Heritage Project. Electric propulsion technologies currently being investigated under this program include pulsed electromagnetic plasma thrusters, magnetoplasmadynamic thrusters, helicon plasma sources as well as the systems models for high power electromagnetic propulsion devices. An investigation and evaluation of pulsed electromagnetic plasma thruster performance at energy levels up to 700 Joules is underway. On-going magnetoplasmadynamic thruster experiments will investigate applied-field performance characteristics of gas-fed MPDs. Plasma characterization of helicon plasma sources will provide additional insights into the operation of this novel propulsion concept. Systems models have been developed for high power electromagnetic propulsion concepts, such as pulsed inductive thrusters and magnetoplasmadynamic thrusters to enable an evaluation of mission-optimized designs.

\section{SUBJECT TERMS} 15. NUMBER OF PAGES

Electric propulsion; Magnetoplasmadynamic thrusters; Pulsed plasma thrusters; Helicon thrusters

\begin{tabular}{|c|c|}
\hline $\begin{array}{c}\text { 17. SECURITY CLASSIFICATION } \\
\text { OF REPORT } \\
\text { Unclassified }\end{array}$ & $\begin{array}{c}\text { 18. SECURITY CLASSIFICATION } \\
\text { OF THIS PAGE } \\
\text { Unclassified }\end{array}$ \\
\hline
\end{tabular}

19. SECURITY CLASSIFICATION OF ABSTRACT

Unclassified
12

16. PRICE CODE 

